\title{
Effectiveness of the canalith repositioning procedure in idiopathic and posttraumatic benign paroxysmal positional vertigo
}

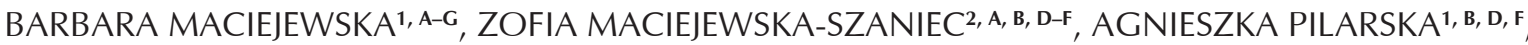

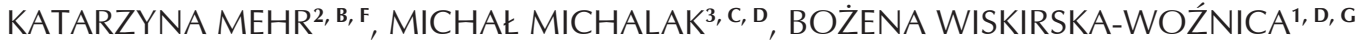 \\ ${ }^{1}$ Chair and Clinic of Phoniatrics and Audiology, Poznan University of Medical Sciences \\ ${ }^{2}$ Clinic of Oral Rehabilitation, Poznan University of Medical Sciences \\ ${ }^{3}$ Chair and Department of Computer Science and Statistics, Poznan University of Medical Sciences
}

A - Study Design, B - Data Collection, C - Statistical Analysis, D - Data Interpretation, E - Manuscript Preparation, $\mathbf{F}$ - Literature Search, $\mathbf{G}$ - Funds Collection

Summary Background. Vertigo as a symptom accompanies many pathological processes leading to damage of the vestibular system at a peripheral or central level. It is a manifestation of systemic diseases. Vertigo is one of the most common causes of presentation of the patient to a general practitioner. One of the most common causes of sudden vertigo is benign paroxysmal positional vertigo (BPPV).

Objectives. Assessment of the effectiveness of the canalith repositioning procedure in idiopathic and posttraumatic BPPV. Material and methods. 50 people with BPPV aged 22-78 (mean $53 \pm 13$ ), divided into 2 groups of 25 subjects each, suffering from posttraumatic (group A, aged $53 \pm 15$ ) and idiopathic (group B, aged $53 \pm 11$ ) vertigo. The treatment was conducted using the Epley manoeuver, controlling its effectiveness by means of the Dix-Hallpike manoeuvre.

Results. All the treated patients benefited from the therapy. The percentage of patients cured after the first two medical manoeuvres was $52 \%(13)$ and $92 \%(23)$ in groups A and B, respectively, which is a statistically significant difference $(p=0.0016)$. Patients in group B had an 18 times higher chance of regression of symptoms as early as after the first medical manoeuvre. The number of performed manoeuvres which guaranteed full effectiveness was on average 1.16 per patient with only one semicircular canal affected, and 3.5 when semicircular canals on both sides were affected.

Conclusions. 1. The application of motor rehabilitation in the course of BPPV is a non-invasive method for treating vertigo with high effectiveness. 2. Trauma in medical history prolongs the treatment of BPPV using manoeuvre. 3. If BPPV affects both sides, the manoeuvre should be repeated more times. 4. The characteristic medical history and risk factors (trauma) facilitate forming a suspicion of the diagnosis with a high probability as early as in the office of a general practitioner.

Key words: treatment, vertigo, motor rehabilitation.

Fam Med Prim Care Rev 2016; 18(3): 278-281

\section{Background}

Vertigo is a common reason for a patient presenting to a general practitioner [1]. A British study involving a population of 2064 subjects aged 18-64 demonstrated that 20\% of people suffered from vertigo at least once a month [2]. The term "dizziness" in Polish may mean different ailments: the illusion of a spinning motion (vertigo in English), as well as uncertainty of gait/instability (disequilibrium in English). Because of the ambiguity of the term "dizziness", and the fear, emotional stress and anxiety of the patient accompanying this symptom, there is a difficulty to determine whether it is a condition requiring urgent intervention, or only a symptom accompanying a benign disease [3]. This is because the etiology of dizziness is varied. It accompanies many pathological processes leading to damage of the vestibular system at a peripheral or central level (labyrinthitis, vestibular neuritis, Meniere's disease). In addition, it can be a manifestation of systemic diseases [3, 4]. It can accompany cardiovascular diseases (arrhythmias, orthostatic hypotony, hypertension), it occurs as a side effect of drugs, appears in the course of neurological (TIA, stroke, multiple sclerosis) or endocrine diseases (diabetes, thyroid dysfunctions), after head and/or neck injury, or is a consequence of improper lifestyle - fa- tigue, stress, or a symptom of psychosomatic diseases [5]. One of the most common causes of dizziness is benign paroxysmal positional vertigo (BPPV) $[3,6,7]$. It is considered to be not only the most common cause of vertigo associated with organs of balance [3, 6, 7] and vertigo of ear-related origin [8], but also the most common cause of vertigo in general, especially in elderly people presenting to a primary care physician (up to 50\%) [9, 10]. Typical symptoms comprise short, lasting several seconds, sudden and severe systemic vertigo concomitant with balance disorders, a feeling of instability, often accompanied by nausea, vomiting, pallor and sweating, causing fear and anxiety in the patient [11]. These symptoms are caused by a specific body movement, e.g. looking aside, behind, bending the head back, moving sideways. They appear during housework, at work, or during a visit to a hairdresser or a dentist. One diagnostic method is the Dix-Hallpike manoeuvre, during which the patient experiences vertigo and nystagmus [6]. In approximately $50 \%$ of cases it is not possible to determine the direct cause (so-called idiopathic BPPV) [6]. Other cases are most frequently associated with injuries or vestibular neuritis [6]. There are also reports that BPPV occurs as a consequence of surgical procedures, including ear-related and dental procedures [12]. It is worth paying attention to BPPV, as it is easy 
to diagnose, including by a general practitioner. With a correctly collected medical history the prognosis is favourable, and there is a possibility of effective treatment.

\section{Objectives}

The aim of the study was to assess the effectiveness of the canalith repositioning procedure in patients suffering from inidiopathic and posttraumatic BPPV.

\section{Material and methods}

The study involved 50 people aged 22-78, mean age 53 \pm 13 years old, diagnosed with BPPV using the Dix-Hallpike diagnostic manoeuvre (positioned on the back, with the head tilted $45^{\circ}$ to the side). In order to exclude other causes of vertigo, each of the subjects underwent an otoneurological examination: caloric reflex test, videostagmography, pure tone audiometry, static posturography, computed tomography of the head - the results were normal. Subjects with fresh ischaemic lesions in the brain (stroke) and vestibulopathy were not enrolled in the study. 2 groups of 25 subjects each, comprising patients with post-injury/posttraumatic (group A) and idiopathic (group B) BPPV (Tab. 1) were created.

\begin{tabular}{|c|c|c|c|c|}
\hline & \multicolumn{2}{|c|}{ Group A } & \multicolumn{2}{|c|}{ Group B } \\
\hline & $n$ & $\%$ & $n$ & $\%$ \\
\hline \multicolumn{5}{|l|}{ Age } \\
\hline$<40$ years old & 6 & 24 & 4 & 16 \\
\hline $40-60$ years old & 11 & 44 & 14 & 56 \\
\hline$>60$ years old & 8 & 32 & 7 & 28 \\
\hline \multicolumn{5}{|l|}{ Sex } \\
\hline Women & 15 & 60 & 15 & 60 \\
\hline Men & 10 & 40 & 10 & 40 \\
\hline
\end{tabular}

The causes of injuries in group A included: car accidents associated with whiplash-type injury - 44\% (11), falls from heights $-16 \%$ (4), implantation of a cochlear implant $-20 \%$ (5), dental procedures $-20 \%$ (5). In the total of both groups ailments were localized on the right side in $52 \%$ (26), on the left side in $38 \%$ (19), and bilaterally in $10 \%$ (5) of the patients. All cases of bilateral symptoms were recorded in group A. The treatment was performed using the Epley repositioning manoeuvre, controlling its efficacy every 7 days by means of the Dix-Hallpike diagnostic manoeuvre. No vertigo or nystagmus in this diagnostic manoeuvre demonstrates regression of symptoms [6]. The Epley medical manoeuvre is a complex of consecutive movements, aimed to remove otoliths from the semicircular canals. Initially, the patient is in a sitting position, and then the head of the patient is rotated $45^{\circ}$ toward the affected side, $90^{\circ}$ in the opposite direction, then another $45^{\circ}$. At the end the patient returns to the sitting position (for a detailed description see [13]). In the absence of effectiveness the treatment was repeated. The material was subjected to statistical analysis using the Statistica PL 10.0 software package (StatSoft). The normality of the distribution of the age variable was confirmed using the Shapiro-Wilk test. In order to examine the significance of differences between the examined groups, Student's t-test was applied, and in the case of qualitative variables the chisquare test of independence or alternatively the Fisher's exact test were applied. The odds ratio, with a 95\% confidence interval for the performed manoeuvre, was determined. The odds ratio was determined for the first, second and third manoeuvres. Estimation of confidence intervals was performed using Woolf's approximation. The tests were considered statistically significant at $p<0.05$.

\section{Results}

The mean age in the whole group was $53 \pm 13$ years, the mean age in group $A-53 \pm 15$, and in group $B-53$ \pm 11 years. Age profile and sex distribution did not significantly differ between groups A and B $(p=0.500)$. In group B a complete regression of ailments in $72 \%$ (18) of the patients was observed as early as after the first manoeuvre, and in another $20 \%$ (5) of the patients the regression of vertigo was obtained after the second manoeuvre; two more subjects recovered after the performance of successive treatments. In group A only $12 \%$ (3 subjects) benefited from the first manoeuvre, and $40 \%$ (10 subjects) from the second one. The percentage of patients recovered up to the second medical manoeuvre was 52\% (13) for group A and 92\% (23) for group $B$, which is a statistically significant difference $(p=0.0016)$. The effectiveness of successive manoeuvres in both groups is presented in Table 2 .

According to the odds ratio, the patients from group B were over 18 times more likely to experience regression as early as after the first medical manoeuvre. Analyzing the effectiveness of the treatment, it was observed that the number of performed manoeuvres which guaranteed full effectiveness was on average 1.16 per patient for patients with only one semicircular canal affected, and 3.5 when semicircular canals on both sides were affected.

\section{Discussion}

BPPV is among the most common causes of dizziness, especially in the population of elderly people [14], which is confirmed by the average age of the subjects (approx. 53 years). In approximately $50 \%$ of cases it is not possible to determine its direct reason (idiopathic BPPV) [6], which was also observed in the study patients. The treatment of choice in the therapy of BPPV comprises the motor manoeuvre (e.g. the Elpey or Semont manoeuvre) - grade A of recommendation $[6,13,15]$. On one hand, this results from the high efficacy of the performed manoeuvre - of up to $80-98 \%$ [9], and on the other hand, from the quick results of the treatment [15]. Although the number of patients with im-

\begin{tabular}{|l|l|l|l|l|l|}
\hline \multicolumn{2}{|l|}{ Table 2. Effectiveness of successive medical manoeuvres in the study groups } \\
\cline { 1 - 5 } Number of manoeuvre & $\begin{array}{l}\text { Number of people with improvement } \\
\text { after successive manoeuvre }\end{array}$ & Odds ratio & Confidence intervals & $p$ (Fisher's exact test) \\
\cline { 2 - 6 } & in group A & in group B & & & \\
\hline 1 & 3 & 18 & 18.857 & $4.252-83.623$ & $p<0.0001$ \\
\hline 2 & 10 & 5 & 3 & $0.4752-18.938$ & $p=0.3898$ \\
\hline 3 & 6 & 1 & 1 & $0.05005-19.978$ & $p=1$ \\
\hline 4 & 6 & 1 & - & - & - \\
\hline
\end{tabular}


provement increased successively in subsequent repetitions in both groups (Tab. 2), patients in group A required more manoeuvres to achieve a positive effect, and their chance for the regression of symptoms after the first manoeuvre was smaller. This is indicated by the more chronic or complicated course of BPPV in the case of injury. Five cases of bilateral vertigo were recorded in the study patients in the group of posttraumatic subjects. In the literature it is reported that posttraumatic BPPV belongs to conditions arising from head injuries, whiplash-type injuries, and surgeries of ears, nose or teeth, and they include approximately $15 \%$ of BPPV cases [6]. Most likely, the chronic or complicated course of BPPV with trauma in medical history results from the mechanism of injury: large accelerations of the head resulting from the force of the action of the injury, which leads to more extensive damage of the otolith organ; in turn drilling into temporal bone, the installation of cochlear implants transfers vibrations from skull bones to the bony labyrinth, causing its mechanical excitation/vibration, similarly as in the case of head injury. Idiopathic BPPV is most probably caused by degenerative lesions of the otolith organ in the inner ear [6]. Spontaneous damage is probably associated with senile changes, hormonal disturbances, and periodic vasospasm [6].

Vertigo may impair life activity, resulting in: a sense of loss of the previous style of functioning, a constant feeling of fear and insecurity caused by a possible attack of symptoms, and therefore related to further functioning in the professional and family spheres (the feeling of a threatening disease), a number of negative emotions: anger, fear, feeling of guilt, sadness, sense of losing control over the body and senses, and of a disability. It leads to frustration and creates a risk of depressive disorders. In consequence it leads to a decline in the quality of life $[17,18]$.

Vertigo is a common problem in medical practice, but also in the practice of a family doctor. It is usually asso- ciated with co-morbidities such as hypertension, coronary heart disease, diseases of the spine, diabetes, or lipid disorders. At the same time, it is among the main reasons for the presentation of patients to a family doctor [16]. However, the above-mentioned conditions are not always the cause of vertigo symptoms. BPPV is also a frequent disease entity, but is not always immediately diagnosed. Meanwhile, its diagnosis and treatment are quick, noninvasive, and effective. However, BPPV should not be underestimated, as intracranial proliferative processes may mimic the symptoms of BPPV, and additionally BPPV may mask a concomitant malignancy $[6,11]$.

A family doctor, exercising holistic patient care, encounters in his/her daily work a very wide range of diseases. He/ /she is the primary care physician and takes the initial decision concerning each diagnosed health problem [16]. The suspicion of BPPV allows for avoiding unnecessary pharmacotherapy, leads to rapid improvement of the quality of life, prevents possible falls, and reduces the stress associated with uncertainty about health conditions.

\section{Conclusions}

1. The application of motor rehabilitation is a non-invasive method with high effectiveness for treating vertigo in the course of BPPV.

2. Trauma in medical history prolongs the treatment of BPPV.

3. If BPPV affects both sides, the manoeuvre should be repeated more times.

4. The characteristic medical history facilitates forming a suspicion of the diagnosis of BPPV with a high probability as early as in the office of a general practitioner, which allows for quick diagnosis and effective specialized treatment.

Source of funding: This work was funded by the authors' resources. Conflict of interest: The authors declare no conflict of interests.

\section{References}

1. Sloane PD. Dizziness in primary care. Results from the National Ambulatory Medical Care Survey. J Fam Pract 1989; 29(1): 33-38.

2. Yardley L, Owen N, Nazareth I, et al. Prevalence and presentation of dizziness in a general practice community sample of working age people. Br J Gen Pract 1998; 48(429): 1131-1135.

3. Prusiński A. Neurologia. In: Latkowski B, Kosiek K, eds. Sygnały alarmowe u chorych i pilne decyzje lekarzy POZ. Warszawa: Wydawnictwo Lekarskie PZWL; 2013: 124-148.

4. Maarsingh OR, Dros J, Schellevis FG, et al. Causes of persistent dizziness in elderly patients in Primary Care. Ann Fam Med 2010; 8(3): 196-205.

5. Colledge NR, Barr-Hamilton RM, Lewis SJ, et al. Evaluation of investigations to diagnose the cause of dizziness in elderly people: a community based controlled study. BMJ 1996; 313(7060): 788-792.

6. Nuti D, Zee D. Positional vertigo and benign paroxysmal positional vertigo. In: Bronstein AM, ed. Oxford textbook of vertigo and imbalance. Oxford: Oxford University Press; 2013: 217-230.

7. Prusiński A. Wprowadzenie: terminologia, klasyfikacja i przyczyny zawrotów głowy. In: Prusiński A, ed. Zawroty głowy. Warszawa: Wydawnictwo Lekarskie PZWL; 2002: 11-22.

8. Brantberg K, Bergenius J. Treatment of anterior benign positional vertigo by canal plugging: a case report. Acta Otolaryngol 2002: 122(1) 28-30.

9. Prusiński A. Geriatryczne aspekty zawrotów i zaburzeń równowagi. In: Prusiński A, ed. Zawroty głowy. Warszawa: Wydawnictwo Lekarskie PZWL; 2002: 228-234.

10. Parnes LS, Agrawal SK, Atlas J. Diagnosis and management of benign paroxysmal positional vertigo (BPPV). CMAJ 2003; 169(7): 681-692.

11. Obrębowski A, Wiskirska-Woźnica B, Maciejewska B, et al. Łagodne napadowe położeniowe zawroty głowy w materiale własnym. Otolar Pol 2006; 60(6): 839-843.

12. Chiarella G, Leopardi G. Benign paroxysmal positional vertigo after dental surgery. Eur Arch Otorhinolaryngol 2008; 265(1): 119-122.

13. Gębska M, Wojciechowska A, Rakowiecka M, et al. Rehabilitacja przedsionkowa u pacjentów z przewlekłymi zaburzeniami równowagi i zawrotami głowy. Fam Med Prim Care Rev 2014; 16(1): 39-43.

14. Iwasaki S, Yamasoba T. Dizziness and imbalance in the elderly: age-related decline in the Vestibular System. Aging Dis 2014; 6(1): 38-47. 
15. da Silva CN. Vertiginous symptoms and objective measures of postural balance in elderly people with benign paroxysmal positional vertigo submitted to the Epley maneuver. Int Arch Otorhinolaryngol 2016; 20(1): 61-68.

16. Bujnowska-Fedak MM, Sapilak BJ, Steciwko A. Epidemiologia schorzeń i struktura zachorowań. Fam Med Prim Care Rev 2011; 13(2): 135-139.

17. Kubacka-Jasiecka D. Kryzys psychologiczny. In: Kubacka-Jasiecka D, ed. Interwencja kryzysowa. Pomoc w kryzysach psychologicznych. Warszawa: Wydawnictwa Akademickie i Profesjonalne; 2010.

18. Schwarzer R. Stress, resources, and proactive coping. Appl Psychol Int Rev 2001; 50: 400-407.

Address for correspondence:

Barbara Maciejewska MD, PhD

Katedra i Klinika Foniatrii i Audiologii UM

ul. Przybyszewskiego 49

60-533 Poznań

Polska

Tel.: +48 504 772-652

E-mail: maciejewskabasia@wp.pl

Received: 29.03.2016

Revised: 18.04.2016

Accepted: 05.05.2016 